being born; so that there remains no evidence of the premature inspiratory efforts having been made. It is therefore only in rare instances that a child which really lived after birth would be believed to be still-born on these grounds.

We have now, we believe, laid before our readers the chief points which have been ascertained by modern investigation with reference to the subject of the respiratory function of the placenta, and of the effects of its interruption. There are, no doubt, questions still undecided, and difficulties yet to be cleared up; but these have but little weight when opposed to the evidence from observation and experiment, which we have been unfolding; and there are, as we think, few doctrines in physiology against which there have not been urged graver objections than those which are employed against this.

\title{
Review IV.
}

On the Causes of Sickness in the Englist Wars, and on the Means of Prevention. By E. A. Parkes, M.D., F.R.S., Professor of Military Hygiène in the Army Medical School. (From the 'Journal of the Royal United Service Institution,' vol. vi. p. 16.)

To our eye these few pages of history appear to rank amongst the most important that have ever been written. Instructive to those engaged in the practice and study of medicine, especially in its application to the health of armies, they are in an equal degree calculated to make the soldier reflect on those divisions of the military art which are most slurred over by writers, and which by mere tacticians are witlessly despised. Nay more, we shall say we would willingly see them pass into the hands of every man that can read and write, so important are they in their general aspect to the nation, so necessary is the diffusion of the lessons which they teach to effect change in the evils they are intended to reform.

The subject of the pamphlet before us is the health of armies considered historically, and in application to our military service. Short and condensed, it makes evident from recent examples how necessary is vigilance, how essential is resource, and how inevitable is disaster when each contents himself with merely doing his appointed share of work, not "looking on the things of others as well as on his own," or interesting himself in the final result.

In the briefest of all possible essays we see marshalled before us the few diseases whose frightful repetition and strong identity seem fated, as long as our nation lasts, to destroy our armies, to embitter our conquests, impoverish the blood of the nation, and neutralize the employment of our wealth.

Not only the devastating and disabling maladies which have left their mark upon our annals are here brought forward for instruction, with details full of interest and enumeration sufficiently complete, but the causes are severally indicated which, by a direct action, invariably produce the results of disease; so true is it that, understanding the 
conditions, you can with much certainty infer the disease, so also, knowing the disease, you can easily lay your hand upon the cause.

"The rations issued at Carthagena in 1741," says our author, "are not mentioned in history; but the scorbutic dysentery soon succeeding scurvy, shows us as certainly as if the diet lists were before us, that hard salt beef and biscuit formed the miserable allowance, scarce deserving the name of food, which was issued to these men."

Nor may we suppose that modern times have excluded the most recognised and most glaring of these causes from operation. In the two first Caffre wars (p. 4) a large proportion of the men became scorbutic. Foregoing the advantages of civilization, it may be said that we brought ourselves to the level of savage life, and fought with blunted weapons and limbs that were maimed. A yet more modern instance lies before us.

"In the first year of the Crimean war the diet was so insufficient, that any one accustomed to the subject would have been able at once, on being informed of the amount, to foresee the inevitable result; yet it was deemed sufficient to support the strength of men in the most trying and exhausting of wars."

From the avowal of $\mathrm{M}^{\circ} \mathrm{Cl}$ eod, in his history of the surgery of that war, "scurvy influenced and complicated every wound .... it wrested more men from us than the conical ball." Again, he says, "It is useless now to inquire why that store of lime-juice which is proved to have lain at Balaklava during two months was not issued to the longing troops." We rejoice at his exoneration of our profession, but cannot acquiesce in so important a matter being wholly laid at the door of a subordinate department-the commissariat. It was but the story of Carthagena over again. The coast of the Black Sea offered abundance of green food and fruit, with wood for fuel, convenient to the use of those who would fetch it; "but perhaps," as Smollett has said, "the general was too much of a gentleman to ask a favour of this kind from his fellow-chief, who, on the other hand, would not derogate so much from his dignity as to offer such assistance unasked."

From such causes mainly, in the most glorious of enterprises, indeed, but in an early part of the Crimean war, perished that small, compact, and model army, of whose composition we may aver that, as regards manhood and perfection of form, the eye rests on nothing like them in the present day.

"Troops well cared for," according to our author, " must be healthy;" but the inveteracy with which these habits of mere neglect recur, lead us to fancy we hold in the sheets now before us some chapter torn from a treatise on human nature, intended to display its recklessness and heedlessness alike. Out of many examples, we shall pause a moment over the recent one of that Burmese war which occurred rather less than forty years ago:

"In both cases," says our author, speaking of the Burmese expedition in 1824, and of the China war in 1840, "the cause of the immense mortality which ensued, or by far the most potent cause, was the food which was issued to the men. In both cases it was thought that men could be maintained, not only in health but in fighting condition, upon diet so bad that no slaveholder in any part of the world, or in any age of the world, would have given it to his slaves. 
Wretched cattle, hastily purchased and driven to Calcutta, were there hastily salted; and on this wretched meat, and almost as wretched biscuit, the troops were kept, when within a few days' sail there was a land of wheat and of rice and of fresh vegetables without end.

"To the immense mortality in the Burmese war (1824) I need scarcely refer. In three or four months some of the regiments lost half their strength ; in eleven months, $1 \cdot 311$ men died out of $2 \cdot 716$. The 13th Foot lost by disease 341 out of 608 men, or 56 per cent. So general was the scurvy that the surgeons were in the habit of examining the gums of the men before a skirmish to prevent any of the men having symptoms of the disease from advancing, as wounds received in that condition of body are most intractable. Malignant malarious fever and scorbutic dysentery were the great agents of destruction."

When one reads such things, it matters little to ask whether the disaster of Carthagena was in this or yonder century, in the past or yet to come. Details as we are now considering them seldom or never reach the general reader in such a form as to interest the nation; it is enough if in the history of a distant war, recounted in all likelihood by some officer of the service, a hint here and there occurs of fever and cholera.' Dysentery is invariably attributed to over-indulgence in fruit; short supplies and deficient commissariat conveyance are slightly mentioned; the fighting is all in all. The period, however, is not so far distant but that it survives in the traditions of the service; can it be true that some of the beef served out to the troops in Burmah had been in store since the Java campaign in 1811? There could then be but one opinion as to its nutritious qualities. ${ }^{2}$ What is most certain is, that it was nauseated and kicked about by the men. We remember hearing from the lips of one officer of his regiment being in such a state that a double dram had to be served out before it could be marched less than a mile from Rangoon to the commissariat store.

"Twenty-six years later, in the expedition to China, the same tragedy was repeated without variation. The history of the Cameronians may be taken as a type of the fate of the whole force, although the amount of sickness was greater than that which prevailed in some other regiments. The Cameronians landed at Chusan, a splendid body of men 900 strong, on the 5th July, 1840. In the first week in August 500 were in hospital; towards the end of August less than 100 mustered on parade. Later in the season the débris of the regiment, under 200 men, were sent to Manilla to recruit, and of them but a fraction ever saw their colours again. The bloodiest battle would have been mockery to this. Doubtless they were to a certain extent in a malarious country, but the malaria was not sufficiently intense to cause so great a loss. Again the simple cause is to be found in the diet."3

\section{Snodgras' Burmese War.}

2 The head of the commissariat is, we believe, liable in money for the goods in store.

3 During the last few months, facts have been prominently brought forward, which display in a striking degree the prophylactic influence of a sound dietary against the poison of malaria. We allude, in the first instance, to the getting in of the harvest in the Roman Campagna under better conditions of diet and shelter, without the usual occurrence of fever, as communicated during the past year to the Royal College of Physicians of London; and, in the next instance, to the circumstance of the total disappearance of ague from Scotland under improved condition of its inhabitants, as remarked upon by Dr. Christison in his address at the last meeting of the Social Science Association.

See also a recent work, Hind's Labrador, regarding the influence of diet in the producticn of night-blindness. 
These instances, as it seems to us, are not without instruction. "As far as diseases are concerned," says our author, "the history of all our wars presents a remarkable sameness." It is to be apprehended that a tendency to "sameness," such as prevails in all organized bodies of men and nations, and nowhere so much as in armies, has occurred side by side with disaster, and stands even now at a point to require correction and vigilance to neutralize its consequences. A remarkable "sameness" certainly displays itself in the military character of the present epoch ; our author does not fear to say, that-

"In the wars toward the end of the last century, and up to the long peace, the commissariat arrangements appear to have been inferior to those of eighty and sixty years before."

In our own days the last China war alone formed a brilliant exception. Under the guidance of good principles we might look for a yet greater improvement, or at least with equal precautions to an equal result.

"The first rule," says our author, "is to provide a diet in the highest degree strengthening and nutritious. It may seem an expensive matter to the state to provide a diet sufficiently varied, but it is not so."

The Great Frederick, in his published instruction to his generals, quoting another's words, says: "The first object in the establishment of an army ought to be making a provision for the belly $;^{1}$ that being the basis and foundation of all operations." His work includes many considerations for the health of troops. Directions are not only given for provisioning men, but horses too; he is careful that every company should be provided with a handmill; while he recommends brewers as objects of particular regard in the captured towns. So before the Russian campaign, under Napoleon I., the greatest interest was displayed by him in particulars as to the nourishment of his troops; these things are, however, much subject to failure, not only from the colossal scale of similar operations, but very much from a want of correlative intelligence and foresight in subordinate commands. Now, the leading idea, not too boldly expressed, in these pages, seems to us to be that the military art, or military economy, as regards an exact attention to hygienic principles, is really not far in advance of earlier ages. Habit tends to make us believe the increasing current of modern improvement to be such, that each art, by an inherent force, improves with advancing civilization, and perfects itself somewhat independently of the virtues and defects of those who practise it. Hygienic principles in war, under whatever denomination, have, however, always been of such extreme urgency, and so intimately connected with success, that every commander of genius and resource, whether in ancient or modern times, must have learnt them from example or precept, as well

1 It was a favourite saying of Frederick, that "an army moved upon its stomach." It is paralleled by the reflection of Napoleon, that "the belly ruled the world;" and The author of 'Anastasius' informs us, that in the battles between the Austrians and the Turks the great struggle was always round the large copper cooking-vessels of the latter, which the under-fed Austrian was as greedy to seize upon as the wellfed heathen was strenuous to defend. The argument for good diet was pithily put to us by a French soldier in these words : "Tel on vit, tel on est." 
as from experience ; and such themes must always have found a place in camp tradition, and in the memories of veteran soldiers; the art of war during the middle ages, and perhaps generally in ancient times, formed more exclusively than now the subject of conversation at home and at the convivial gathering; in our day, observation is directed to a more varied field; commerce, literature, science, fine arts, have distracted attention from the once absorbing topic of war, and it is not too much to say, that in modern civilized societies the tendency is to make that the property of a caste which, in fact, is highly wrought in to the interest of all.

But of all causes which in later days have influenced the soldiers' health, none we believe have been of extent equal to the personal character of those leading spirits who mould the age in part or whole to their faculties. The bias of imitation is so much more considerable in man than the reasoning principle, that every age and people fluctuates in cycles of national character according as such prominent persons inflnence it. The wry neck of Alexander, and the round back of Napoleon, have found each in their time and nation an abundance of servile imitators. The latter of these men, though not naturally cruel in disposition, became so in act and deed through the operation of a fallacious philosophy. Neither he nor the Great Frederick ever fairly understood the sanctity of human life; with them it was very much a pawn to play with, a unit on the board; the exterior of the soldier under Napoleon was made flashy and imposing, but the constitutional vigour of his frame was ill-maintained ; moreover, this spirit in the chief very largely pervaded the officers under his command. Wellington was not a man who, during his military career at least, cultivated or nourished to a marked extent the gentler and kindlier features of humanity. Moreover, in his day, the times were quick and urgent, and he, as their single prop, ${ }^{1}$ was absorbed in the main result. A certain hardness and inflexibility of character, with a calculating head rather than a personal heroism; a hardness wrought, as it appears in some respects, into obtuseness, by a somewhat faulty and exceptional early training, left him in most essentials sagacious ; in nicer points it is to be feared he was ever fated to be un-enlightened. These men were without an exact parallel in former times. It is open to conjecture that there may be several bad copies of them now. There is nothing, we may add, that more detracts from the character of the present ruler of the French than, with many blandishments and indulgences, the imperfect hygiene of the soldiers under his rule. ${ }^{2}$

1 We can find no other explanation or excuse for Pitt, whose neglect of the seamen's complaints previous to the mutiny at the Nore is properly characterized as a gross political blunder.

2 One visit to a French barrack will confirm this. It has been reserved for the ready perception and simple conviction of an admirable woman to urge this matter with more propriety and force than anyone else could employ upon the attention of her consort. We refer to the Empress's inspired letter, or telegram, from Cadiz, in October last, a propos of a French transport with troops for Mexico, which had touched there. "Sire, on traite vos soldats pire que les nègres." As we write, we rejoice to hear that the wretched barrack accommodation at Avignon is at last undergoing change, with several particulars of improvement. 
Notwithstanding the misconceptions to which modern historians have lent themselves, by which, however, it is pleasing to observe how few have been misled, we have only to turn to the pages of our Robert Jackson to see how different was the cast of character in an earlier time.

"Marlborough," says this prince of army surgeons, "was modest and humble, religious without ostentation, and full of sensibility to the human species." 1

If a commander is like this, the subalterns take their cue from his behaviour. Humanity gives price to valour, which, as a single quality, is often the property of the brute. As regards Turenne, we know his troops named him by the tender epithet of father.

Partly to convince those who are too sickly in love with modern times and dates, we will quote from our author some of the details of the wars of Marlborough, and those soon after him :

"In the wars of Marlborough, those in Flanders and Germany, in 1742 and in 1760 , the men were better fed than in many later campaigns; salt meat seems happily to have been little used. The colonels of the regiments appear to have been the chief purveyors: each colonel contracted with butchers, who drove with the army herds both of sheep and oxen for slaughter. Fresh meat, at, any rate, was thus procured, and we know from the writings of Donald Munro, that in 1760, the army surgeons strongly insisted on the issue of bread and fresh vegetables; fruits also seem largely used, and in this way the ravages of scurvy appear to have been almost prevented. The wars in Flanders in 1742, and in Germany in 1760, have been very carefully recorded; perhaps more so than any other war, with the exception of the Russian war of 1854.5. In both these wars, at certain periods, the men were exposed greatly to inclemencies of weather. It was then seen, that if men are well fed and can be kept dry, they can bear great cold. The winter of 1742 was extremely severe, and in April, when the troops commenced their march, there were extraordinary snows for seventeen days. The troops marched through these storms, but were every night received into warm houses. Out of the 16,000 men, not twenty were lost. Again, in the German war in 1760, some regiments made a winter campaign on the borders of the Lower Rhine; they were exposed to great inclemencies of weather, to great hardships, and to extreme cold, yet they were very healthy, much more so than the troops left in the fixed camp at Warburg, who, it may be supposed, must have been in the possession of much greater comforts. This was owing to their good food and good clothing. At that time, 1760 , every soldier wore a flannel waistcoat, a custom which has now unfortunately disappeared. This custom was commenced by gifts from the Quakers to the army, 1745-6, and it was found to be attended with the greatest possible benefit. In 1760, the Government issued warm clothing of this description, and in addition there was a very large private subscription in England, and blankets, greatcoats, underclothing, shoes, horses, and were wrapped in waterproof clothing. Each company had its own

Here we have, in effect, what is far from carried out in the present day-viz., the underclothing of the soldier carefully attended to, on of the most important particulars of his personal economy. This, with bodily cleanliness, is of more real importance than personal appearance

1 Jackson on Armies. 
on parade. In combating the effects of cold, the experience of the American War of Independence is appealed to, to show that the daily use of spirits is always hurtful, and how material hot liquids are to the comfort and health of the soldier :

"The same fact, that men can bear great exposure to cold if properly fed and clothed, was established in the American War of Independence. Some of the Rangers were out during the winter, and escaped entirely the diseases produced by cold. They attributed their immunity in a great measure to the use of hot ginger tea. Every man carried a piece of ginger in his pocket, and would on no account be without it. With this they made hot tea, and they found this much more comforting than spirits, which appear to have been in a great measure disused among them. Hot infusions of garlic and infusions of horseradish were also used for this purpose, until the more common employment of hot tea and coffee supplied us with the means which may, perhaps, be considered even better adapted to protect the body against exposure to cold."

The yearly pressure of a blind economy enforced upon Administrations, and a want of burning sympathy of men of influence from the army ranks, have combined to leave the "condition of the soldier" question so much in arrear, that above all other questions it seems clogged with unaccountable difficulty in retrieving ground that has been lost; the inferior and disadvantageous condition of the soldier, received into acceptance by power of custom, is strangely now at variance with the military adage "that every soldier is a gentleman."

From matter, all of which is of the highest value, we shall select two points for observation and remark. One of them addresses itself to commanders of forces; the second to governments. The first regards the site of malarious and infected localities; the second concerus the enlistment of men. In treating of the malarious districts, our author mentions the fact, in comments on the Walcheren expedition, that as early as the year 1747 Sir John Pringle had already described the unhealthiness of Walcheren and South Beveland. So great was the sickness that in many corps six-sevenths of the men were in hospital at that time. Our author resumes :

"This ought to have ever prevented the expedition in August, 1809, from being undertaken; but, as if it was not warning enough, we have it mentioned that the English force, in 1809, found a Dutch regiment there which in three years lost 715 out of 800 men; this was the type of its own fate. On the 14th of September, seven weeks after leaving England, out of 15,000 men 10,000 were in hospital."

We also find an instance recorded of a regiment encamping, against medical advice, on the marshy grounds of the Pedee river in America during the War of Independence. Caught as in a trap, they could

1 Severe and prolonged cold subjects the frame to disease, and we might say to pestilence, in a degree perhaps equal to extremes of heat; when rigorous, it is far from having that strengthening effect upon the frame that is commonly supposed. In the terrible cold of the expedition to North Holland, in 1799, when the cold was more intense than in the Russian campaign in 1812, the contagious fever was accom. panied by maniacal symptoms resembling those described in the plague of Athens. A severe winter frequently precedes the Oriental plague. These is no more fatal mistake than the constant strain in the endeavouring to harden the soldier, who, as a rule, has far less vital power than his officer. 
not, from mere feebleness, remove their sick. Those of the men who were strong enough to leave the banks of the river quickly improved on the march, while " of those embarked in boats few were heard of again."

As regards old camping-grounds the following: In the expedition to Egypt from India, in 1801, the army, after excessive hardships amid burning heat, reached the Nile. They descended that river for four hundred miles, and landed at Ghiza.

"They found there the 89th Regiment very sickly; scarcely fifty men mustered on parade. This should have been considered the touchstone by which the sanitary condition of Ghiza was to be judged. However, the army was there disembarked, being then, to use the words of Sir James McGrigor, 'uncommonly healthy.' In less than a week they sent into the hospital ten per cent. of their force; in three weeks there were a thousand sick out of the eight thousand men; in four weeks there were twelve hundred sick; then the army moved to Rosetta. We must therefore consider that no less than fifteen per cent. of that force had in that short space of time been in the hospital, and one-fourth of the duty-men, in all probability, must have passed through the hospital. The diseases produced in this short time were attended with very slight mortality. They were chiefly fevers which appear not to have been of malarious origin, but chiefly of that kind-yet little investigated or understood-which are known by the name of the bilious remittent or the bilious typhoid, and the bilious relapsing fevers of the Mediterranean and Egypt. There were also slight dysenteries and some ophthalmia, but no plague till afterwards, when the army got to Rosetta. It was supposed at one time that the diseases produced at Ghiza were owing to the marshes in the neighbourhood; but this is rendered improbable-first, from the fact that, as far as can be known from the accounts of the diseases, which are very short and imperfect, the malarious taint did not form any grand element in these diseases; and secondly, from the following fact-Ghiza for months had been an encamping-ground of a succession of bodies of troops, Turks, Mamelukes, French, and then English. The whole country was covered with putrid effluvia. At a subsequent period, when time had been given for the dissipation and com. plete decomposition and elimination of all these putrid remains, Ghiza was again occupied, and was found to be healthy; therefore it would appear certain that the condition of the camp was the cause which led to the great amount of sickness in the expeditionary force."

We shall now refer to a second vital error which is of singular persistence in our nation. We allude to those sudden enlistments which, under some impatience of circumstances not duly provided for, have been had recourse to, against all the teachings of experience, each time much upon the same plan.

This fault is only stigmatized in a note appended to our author's text, and perhaps on that account we shall give to it more prominence. ${ }^{1}$ The dirty famine-struck recruit is indeed of doubtful value on his own account, and he is often a source of contagious disorder to the soldiers. ${ }^{2}$ A consideration of the nature of the contagious fevers which affected the British troops about the close of the last and early part of this century show them to have partaken largely of the nature of synocha,

1 See account of the British Legion in Spain, p. 12.

2 Des enfans qui encombrent les routes et les hôpitaux. 
or what is now called relapsing or famine fever. They seemingly flowed from this source of enlistment, and spread widely and persistently. The plan of allowing candidates for commissions in the army to scrape together a set of boyish raggamuffins ${ }^{1}$ has repeatedly been had recourse to, and even as late as the Crimean war. We will quote what Robert Jackson has said on this subject:

"It was believed, not without evidence, that the seeds of contagious fever were introduced into many regiments of the line in 1795 by recruits from independent companies. Under the operation of a judicious system of economical regulation, the progress of a disease thus introduced might have been checked - the disease itself banished. Good regulations did not exist at that time; the value of a soldier was estimated in a false scale, and from that false estimate measures originated which threatened to disorganize the army. Rank and command were more certainly obtained by the money of a schoolboy and the activity of a crimp than by actual knowledge of military duty and hardearned experience in the fields of war. Money had purchased one step, and with money another had to be purchased.

"The cbances were watched with eagerness, and the soldiers which were the subject of the traffic passed from hand to hand with the same indifference as counters at a gaming-table. This practice has fortunately given way to a better order of things. The materials of our army are not only better in their own nature, but the economical regulations are better digested and more rigidly practised than they were at the period alluded to; yet, notwitbstanding these advantages, sickness has been sometimes great among the troops on service since the years 1794 and 1795 , and with all the light that might have been derived from experience, it is only of recent date that the practice of accumulating the military sick into military hospitals-a practice more destructive of human life than the most sanguinary battles in the field-has been annulled, or only resorted to under necessities."

We bring this extract the more willingly under the eyes of our readers, as some tendency has lately been displayed to return to the system of general hospitals or hospital depôts, in the teeth of old experience. The general absence of relapsing fever from England since 1855, and confidence in improved sanitary arrangements, may strengthen the purpose of those advocating such views. The abandonment of the sick depôts in favour of the regimental system is calculated by Jackson to have checked the mortality which was "prodigiously great" in the early part of the Peninsular War. He esti- . mates that this reform alone gave ten thousand firelocks to the

1 In the armies of the Roman Republic, according to Polybius, the military service was only accorded to those among the citizens who were two grades removed from pauperism. The qualification was in an income of 4000 asses. The proletarians had but 1500 . The a capite censi were paupers. Any slave who had intruded himself into the ranks of the army, even though honourably scarred, was infallibly punished with death. In the reconstruction society by Charlemagne, the extent of landed possession was taken as the basis of personal military service and contribution. The army was made to consist wholly of proprietors of the soil. In this way the scum of armies, fostered by his predecessors, was purged out.-See Barginet, Hist. du Gouvernement Féodal. If, as we have heard, the "right sort," in our day, is not forthcoming, the cause must be found in the social and moral conditions of the service. Honestas enim idoneum militem reddit.

2 Jackson on Contagious Fever, 1819. 
general in command, and that the annual saving of human life to the army amounted to not fewer than five thousand souls. "I would not err, perhaps," he says, "if I said one-third more."

In short, it turned the tide of victory.

For striking accounts of spotted typhus and other scourges we refer to the author's pages and to those of Dr. Murchison; the survey, though exquisitely painful, ${ }^{1}$ is necessary to make one fully apprehend, and in a lively manner, what war actually is. ${ }^{2}$ Jackson, in his 'Treatise on Fever,' invokes the attention of statesmen and generals, as well as physicians, who superintend the medical concerns of armies, but laments that the "words of a physician are ordinarily spoken to the winds." He fathers the prevalence of contagious fever in his day " on the carelessness, indifference, error, prejudice, or self-conceit of the great, who will not condescend to be instructed by the humble ;" but this is not without exception, and there are names enshrined in his pages which shine bright even now.

"The 93rd," says Jackson, "was sickly when it arrived at Spike Island. It embarked with a long list of sick, and with presentiment of increase; but the sickness, instead of increasing, diminished during detention in the harbour, and more remarkably still on the passage to Barbadoes. I do not assert positively that this improvement arose from the management of the officer who was entrusted with the command; but, whatever the actual cause of the improvement, the unwearied diligence and affectionate care of Lieut.-Colonel Gamnel to the concerns of the soldier, on every occasion where his conduct fell under my notice, as they impressed me with a high respect for his character at the time, so they have left with me a strong feeling of veneration for his memory. Besides the 92rd, the 29th Light Dragoons arrived at Cove in a sickly state. The disease prevailed in both the transports in which the corps was embarked at the time it arrived at the rendezvous at Cove: it was banished from the one in which the commanding officer, Lieut.-Colonel Hay himself, was; it continued in the other. The fact is striking. I was disposed to ascribe it at the time to the judicious care and attention of Lieut.-Colonel Hay, who was then esteemed, and apparently with good cause, a man of sound judgment and superior knowledge in matters which relate to military economy."

On the whole, it may be considered probable that from the superior thoughtfulness of individual character in our nation, and it is to be hoped from the predominance of a reigning humanity founded on Christian principles (though we would not be thought to ignore theïr influence in other countries), our armies have been in a less degree than

1 According to Dr. Murchison, one half of the French in the Crimea attacked with typhus fever died. See his work on Fever, p. 225.

2 We may remark of spotted typhus, the type of European pestilence in the present epoch, that it is so allied to true plague that, in the history of that disease, it is found commonly to precede it; and this also becomes spotted typhus in its decline. symptom the bubo; they are birds of the same Fortunately for mankind, the co-operation of seme nest, and only not inseparable. plague. What strikes the cor seral causes seems necessary to create extent and intensity the medical reader with some surprise is, that fevers of such The cases of spotted fever lately or describes, in no case passed into true plague. army source, and, though few noticed at Philadelphia seem clearly referable to an July, 1863. 
those of foreign states subject to the results of hygienic neglect. Such errors as those of Carthagena, and Walcheren, and the early Crimean campaign, have been followed by a quick rebound of the national heart; and the military administration have repeatedly found it necessary to render an account of its past proceedings to the nation in minute particulars of regulation and discipline.

To what purpose, it may be asked, do we ransack history for elucidation of truths which are plain and incontrovertible? It is that they require to be received in their fullest force; it is the so-called practical men,- by which we mean men punctual in duty, but little fertile in expedient, less wealthy in mental gifts - that we must accuse of maldirection in great operations of the field. In vain shall the medical officer seek to make an impression on the chief whose mental gifts are those of a sabreur; electric in the onset, rigid in discipline, but afterwards unprepared to cope with the slow occasions of destructive decay or with the assaults of malarious and zymotic poison.

"Previously to the battle of Dettingen," says our author, "the men had been extremely healthy, after the battle they were exposed to wet and cold for two or three days; the consequence was that an attack of dysentery occurred, and was so general that half the army was affected by it. Had this occurred a few days previously, it is by no means improbable that the strenuous exertions which alone won the battle of Dettingen would have been impossible."

The enumeration of causes and of remedial agencies, and the multiplication of instances, though worthy of note, are far from being all that is required for the instruction of one in command. To secure the soldier from deprivation, and from perishing or suffering through inclemencies of the air and seasons, requires at once vigilance and contrivance. Military hygiene, except in its main features, is not invariably a simple affair. ${ }^{1}$ In our nation alone, under imperfect moral teaching, the term genius $^{2}$ has tended to become synonymous with eccentricity; and ability or adaptability displayed in various things is rather counted as disabling for trust in service, social and public ; an enlarged capacity, however, and that fertility in resource which is fed by observation and comparison, is precisely what we hope for and what we require in the conduct of our future campaigns; the variety of operations incident to our service renders it the most suggestive of any; it is not impossible that some variation of type in military character may react upon the traditions of the early part of the century. It is, we hope, no treason to say that in the latter end of the wars of Napoleon and Wellington a class of men came to the front in whom a smart attention to technical detail and flattering alertness in obedience superseded all speculative and all

1 The first quality of a commander, says Marshal Saxe, is courage; the second is genius, which should be strong and fertile in expedients; the third is health. 'Reveries and Memories,' by Marshal Saxe.

War is a trade for the ignorant, and a science for men of genius. Chevalier Folard, Sd.

2 We may also affirm that military hygiene is a progressive science. 
intelligent conception of duty. ${ }^{1}$ Hence the superior considerations of health and subsistence fell into abeyance, or into a second line of importance. It is with a conviction that a due attention to hygienic laws will stamp a new era on our country's greatness in arms, and supply very much to make our strength secure, that we instance that fulness of resource and freedom from class prejudice which comes of reading, conversation, and the searching into many things, as being most necessary to the accomplished commander of troops. The explanation of his disasters are otherwise likely to appear strange to him, as in the extract before us :-

"And yet, when asked by the officers in command what extraordinary cause could be assigned for an amount of sickness and mortality truly alarming, something of incredulity has stolen over the countenances of my hearers while the natural causes above described were detailed; so little are we inclined to believe that great effects can be produced by the action of common causes."

The commander should be so far advanced in the study of the laws of health as in some sort to associate himself with the physician in the cares of his charge. There will then be no jealousies either from headquarters or in joint operations, and the character of the medical officer in proportion to his earnestness and ability, will carry more weight with it than it does now. ${ }^{2}$

We shall press this subject closer by bringing to recollection so humble an instance as that of Captain Cook : a familiar exemplar in the memory of our people. Emerging from a letterless boyhood, this man acquired repute as astronomer, mariner, and geographer; he was useful and clever in medical matters, and we may add not unskilled as an experimenter; we may add, also, as botanist and brewer. It is strange how a little knowledge thrives with some and rusts in the hands of many. The fatal sickness which seized on his crew in the Indian Archipelago, in returning from his first voyage round the world, opened Cook's mind to the importance of the sea scurvy-a disease then held to be incurable; and from that time he studied it with attention, until he had arrived at a masterly treatment of the disease. A better proof of which could not be given than the fact that in his second voyage, out of two crews, amounting to 197 men, during an absence of three years he lost but one man by sickness. His stores of "salted cabbage, sour crout, marmalade of carrots, portable soup, inspissated juice of wort and beer, mustard, etc.," do not alone account for this. Attention to nice points of hygiene and to physiological

1 It is well known that the latter part of Frederick the Great's rule favoured the same cast of character, and, by strangling thought and reflection, acted perniciously on the spirit of the times, and on the fortunes of his nation. This was amply experienced in the Prussian army, whose tactics we were then borrowing, and at the time something of that spirit found its way over here.

${ }_{2}$ We may instance Major-General Nott as an officer who, without any brilliant fortune in the field, owed a most triumphant success to the skill and foresight with which he conducted his commissariat arrangernents. We must remember, also, that he knew how to exempt a conscientious medical officer in a censure which in. cluded all the other officers of a regiment. See Life of Nott. 
views combined to give the result. It is not an ordinary man who would have set his sailors to work in New Zealand to brew beer from a tree resembling the American spruce, knowing that with his inspissated juice of wort and molasses it would make a very wholesome beverage, and correct the deficiency of esculent vegetables, of which the country appeared to be destitute.

With such ingenious minds, association affords the highest degree of pleasure ; and let us insist that it was in no small measure by availing himself of the intelligence of our profession that he was able to perfect his views of hygiene.

In the present day and time we are so far still in fæcê Romuli, that we may say with an author already quoted, when lamenting that hospital mortality does not occur so much from disease in its own simple nature as from artificial aggravations through misapprehensions of causes and conditions-

"It is not difficult for the physician to say what may be done for prevention; but he can rarely do more than say that he has not authority to act. The medical art is a science, but it is a science of difficult attainment. If attained, it is perhaps only in the evening of a long life spent in the daily search of it; and as not of easy discovery, it cannot well be supposed that a commissary of war or a military commandant of hospitals should be possessed of it. Yet to such the health-concerns of armies, and the control of army medical officers, appear to be committed, in most of the military services of the greater Powers of Europe."

In the British service, though there is much of the old spirit remaining, much that is retrograde in tendency, we may allow that the description only generally applies. At the same time, we will not disguise from ourselves that it is to the superior spirit of the nobles and privileged of our land that our profession has to look for support in the ranks of the army. The value set upon us by the military class will ever be too low. The soldier is too much in the habit of referring all things to himself, and the gentler arts and virtues seldom grow kindly under his dictation.

In our reflections on the sad results of deficiencies in military hygiene, we would not lead it to be inferred that the best advice, offered with the most steady, uncompromising courage, has invariably been at the service of our commanders. Imperfect views may occasionally intervene; there may be a relapse from the lessons of experience in the minds of our profession. If Jackson's instructions in his chapter on the use of transports had been fully borne in mind, troops affected with cholera would hardly have been sent out to sea for a change, as they were from Varna. On its coming on to blow, and the hatches fastened down, death dealt his blows doubly and trebly quick. This pained us at the time, and has dwelt on our memory till now. We shall never fail honestly to lay open to view any principle or practice prejudicial to humanity. The attention that has lately been given to these subjects, supported by two most worthy names, has not yet died out. Born of urgent circumstances, it has displayed as yet more of the instability of fashion than of the robustness of enduring strength. We may point to 
the publication of the 'Minutes of the Commission for investigating the Sanitary Condition of the Troops in India' (a notice of which will be found in our last number, p. 181), one of the most favourable steps in this direction on which we have to congratulate ourselves, while it has revealed a source of weakness to our state and a scandal to our civilization which is hardly credible. ${ }^{1}$

It is almost distinctive of that field of disease which associates itself with war, that it is but in a minor degree subject to operations of cure, preventive means constituting the greater part of the science. This leads directly to the consideration whether ancient civilization was at any time more advanced than ours in precaution against such disasters. Our author seems to be of the opinion that such was the case. He makes, indeed, an argumentum ad verecundiam to the Horse Guards, founded on the immunity which the Romans enjoyed in their vast undertakings. With us every war, however glorious in effort and success, is pregnant of lessons in camp disorder. ${ }^{2}$ In their history it is quite different. Notices of a similar kind are most infrequent. None would be more averse than ourselves to place this subject on a false basis. The inhumanity of man to man in the heathen world is what we have practically little power of conceiving in the present day. ${ }^{3}$ Indeed, we read marvellously little of the wounded in the relation of battles in ancient history. We can just now remember it but once in Arrian, where Alexander is mentioned as visiting the wounded after the battle of Arbela, although hurt in the thigh himself. ${ }^{4}$ This conqueror is said to have owed the health of his troops in great measure to changing his camp frequently. His great losses in returning from the Indus to Persia were due to excessive heat and want of water. But to resume, the comparison of the ancient with modern times is full of instruction, and it affords a great lesson in the startling contrast shown between commercial states and those of an original military bent. In one case, we meet with the constant recurrence of camp disease; with the others it seems very rare, and especially so with the Romans.

To treat of Greek history, in the first place, we pass over the siege of Troy, and shall first quote Herodotus, viii. chap. 115, to show that

1 In a few words, it may be stated that we hold India on the terms of losing five British regiments by sickness there annually, at the lowest computation.

We would not lead it to be inferred, however, that reports any more than reviews are sure guarantees for progress and reform. They at least may constitute some of the conditions of each. There are responsibilities other than those of public writers ; and commissioners who never yet, according to our experience, have played more than a subordinate part in effecting social change.

2 The sudden conquest of the Havannah in the early part of George the Third's reign was the most lucrative, as well as the most heroic of enterprises; its plunder equalled national subsidy. During the siege the want of water, and total want of good provisions, caused disease among our troops to rage like a fearful pestilence. There perished Bathurst, the much-loved physician, Johnson's co-partner in the "Adventurer,' and its editor. "May my country," wrote Johnson, "never be cursed by such another conquest."

3 See Niebuhr's Lectures on the History of Rome. Lecture 13. Vol. iv.

$$
4 \text { Arrian's History, chap. xii. }
$$


the Persian army, in its return from the invasion of Greece, was seized with pestilence and dysentery. We must note the pestilence of Athens, when all the city became a crowded camp under the external pressure of war. This is described by Hippocrates and Thucydides. The latter relates how (probably hoping to relieve the pressure of population) an expedition of 4000 men was despatched to assist in the siege of Potidæa, under the command of Hagnon, and that they carried the infection with them, to the great detriment of those engaged in the siege; so that Hagnon was compelled to re-embark after forty days with a loss of 1700 men of the troops he had brought. to Potidæa.

In Rome, also, one at least of their early pestilences ${ }^{1}$ (291 U.c.) was due to the accumulation of men in the city under the ravages of the enemy, with the aggravation of much cattle collected there, which at least in the pestilence of Athens they were free from, the Athenians having sent their cattle to Eubœa and the islands. In neither of these instances did the pestilence extend to the neighbouring country. Under such circumstances we may consider these cities as unhealthy camps. $^{2} \quad$ But generally we will affirm that as regards ancient history the chief sanitary interest centres in Syracuse and its sieges. There the Carthaginians especially were most unfortunate, and not there alone. Carthage, it is to be remembered, is that state whose civil constitution, according to the opinion of Aristotle, was the best in existence, and as near as possible to perfection. In the yesir 395 B.c. the Carthaginians were engaged with their allies in the siege of Syracuse, which alone remained to be subdued of all Sicily. We shall relate what befel their army:

"But as to the Carthaginians after they had ruined the suburbs and rifled and plundered the temples of Ceres and Proserpine, a plague seized upon their army; and the more to increase and sharpen the vengeance of the gods upon them, both the time of the year and the multitude of men thronging together greatly contributed to the enhancement and aggravation of their misery, for the summer was hotter than ordinary, and the place itself was the great occasion that the distemper raged above all bounds; for the Athenians in that very same place, not long before, were in multitudes swept away by the plague, for it was a marshy and spungy ground. In the beginning of the distemper, before the sun rose through the coldness of the air that came off from the water, their bodies would fall a shaking and a trembling; but about noon, being so closely pent up together, they were choked with the heat. The infection was brought

1 Those great pestilences which have formed eras in the world's history we will not, by a forced construction, attribute to human agency, although doubtless, in some degree subject to alleviation from human aid and sympathy. These we entirely attribute to cosmical influences. Such afflicted the Roman State both during the Republic and the Empire, and have occurred to as great an extent during the Christian era. There are parts of the world which, from volcanic or other earth-born influences, seem ever smouldering with disease.

2 The conditions which are common to a town and an encampment cannot be too often urged on the military man. The same laws of hygiene apply to both. By studying causes as they tell upon home life and city life, he will best learn to deal with disease in campaigns. Every cause of blood-deterioration lays the frame open to epidemic disorder; and once it is established, the most robust are often those who become the subjects of contagion the earliest and most frequently. 
in among them by the south wind, which swept them away in heaps, and for a while they buried them; but the number of dead increasing to that degree that those who attended the sick were likewise cut off, none durst approach the infected, and (besides the want of attendance) the distemper seemed to be incurable. For, first, catarrhs and swellings of the throat were caused by the stench of the bodies that lay unburied, and the putrefaction of the soil. Then followed fevers, pains in the back, heaviness in the loins, dysenteries, and blotches and boils over all the body. Thus many were tormented by this plague; others were struck mad, and ran about the camp like wild beasts and beat every one they met. All the help of the physicians was vain, both by the violence of the distemper and the sudden despatch it made of many; for in the midst of great pains and horrible torments they died commonly on the fifth or at most the sixth day, so that they who died by the war were accounted happy by all; and it was further observable that all that attended on the sick died of the same distemper; and that which aggravated the misery was that none were willing to come near to the distressed and languishing persons in order to administer to them any sort of help; for not only strangers, but even brothers and dear and familiar friends and acquaintances, were forced for fear of the affection to avoid and forsake one another."'

The Carthaginians are said to have been witnesses of the carcasses of 150,000 of their own men dead of the plague. This loss was rapidly followed by a crisis in their affairs, from which the state and city were saved as by a miracle. And thus, the historian adds, "was a great turn and change in Carthaginian affairs, by which one may learn that whoever they be that beyond measure exalt themselves, may come in a short time to be convinced how weak and inconsiderable they are."

We shall now borrow from Livy ${ }^{2}$ his account of the siege of Syracuse by the Romans under Marcellus, when it was defended by a Carthaginian fleet and army, 212 B.c. :

"It was autumn, and the places where they lay (both armies) were in their nature unwholesome, but much more so on the outside of the city than within, and the heat was so intense as to impair the health of almost every person in both the camps. At first the insalubrity of the season and soil produced both sicknesses and death; afterwards, the attendance on the sick and the handling of them spread the contagion far and wide, insomuch that all who were seized by it either died neglected and forsaken, or also infecting such as ventured to take care of them, these were carried off also. Scarcely anything was seen but funerals, and both day and night lamentations from every side rang in their ears. At last, habituated to these scenes of woe, they contracted such savageness, that so far from attending the deceased with tears and sorrowings they would not even carry them out and inter them, so that they lay scattered over the ground in the view of all, and who were in constant expectation of a similar fate. Thus the dead contributed to the destruction of the sick, and the sick to that of the healtly by the apprehensions which they excited, and by the noisome stench of their bodies, whilst some, wishing rather to die by the sword, singly assailed the enemy's posts. But the distemper raged with much greater fury in the Carthaginian camp than in that of the Romans, for the latter by lying so long before Syracuse were become more hardened against the air and the rains. Of the enemy's troops the Sicilians, as soon as they saw that the spreading of the distemper was owing to an unhealthy situation, left it and retired to the several cities in the neighbourhood which were of

1 Diodorus Siculus, xiv. 70.

2 Book xxv. chap. 25. 
their party; but the Carthaginians, who had no place of retreat, together with their commanders Hippocrates and Himilco, perished to a man. Marcellus, when he perceived the violence of the disorder increasing, had removed his troops into the city, where, being comfortably lodged and sheltered from the inclemency of the air, their impaired constitutions were soon restored; nevertheless great numbers of Roman soldiers were swept away by this pestilence."

Not only in Sicily, but in Spain and in Africa, do we read of pestilence afflicting the armies of the Carthaginian state; and it is singular what infrequent mention of it occurs in the annals of the standing armies of the Roman republic. If in the early days of the Republic the Roman soldier was badly fed, he seems at least always to have had wheat, ${ }^{1}$ and we know, after the second Punic War, a meat ration. In later times he was both well paid and fed. With the Romans, we are informed, the military position was secondary to perfection and regularity of their encampment. There were ædiles of the camp, and cleanliness was enforced by severest discipline. We are ignorant of their medical appointments, but under the Empire, and later, we know that the professors of medicine had a social rank even above what obtains in the present day.

The army sent by Augustus Cæsar to the conquest and exploration of Arabia affords the fullest instance of loss and suffering to Roman troops from causes other than those of conflict, and we shall remark upon it on that account. The general, Alius Gallus, seems to have laid his plans badly in the first instance, and was all along under the influence of a traitorous guidance. He had to operate through a difficult, unknown country never before or since subdued, with dry parching heat and great want of water, which made itself felt to a great extent (as it had sometimes to be carried on the backs of camels), and interfered greatly with his progress and success; consequently his losses were immense. He was obliged to stay an entire summer and winter at Leuce Come, in A. Nabatæa, to recruit his troops from disease. This we may conjecture, from the words of Strabo, consisted mainly of the nature of scurvy, though described by him as peculiar to the East. Count de Joinville, in later times, attributed the same disease to Eastern influences, while with us, in Western Europe, it has always been considered a disease of the North. ${ }^{2}$

The names which Strabo has transmitted to us; of diseases in these troops, are stomacacce, a disease affecting the mouth, and sclerotyrbe,

1 Barley was reserved as a punishment for the Roman soldier, and leguminous food was somewhat abhorrent to him, but occasionally resorted to. A double ration of wheat, or a ration and a half, was an instrument of reward. Hence the words duplicarii, duplares, sesqui-plares, to distinguish soldiers who received them. Papirius Cursor (435 U.C.), a most distinguished general, and evidently a pet of the historian, seems to have been a strong fellow. Livy mentions that he was the best runner of his day, and that he never spared his men. As germane to our matter, we notice that from constitution or practice, he was a famous eater (cibi vinique capacissimus).

2 In the most northern parts of Europe, besides lupus and leprosy, which linger on the coasts, there still exists a wide-spread and almost general "evil" among the popu; lations, to which it would be difficult to assign any other so comprehensive a term, and which results from bad food, damp and cold operating on successive generations. 
a kind of paralysis, according to him, in the legs, attributed to the water and the plants partaken of by the soldiers as their cause. The notices of disease in the annals of the Roman army are unaccountably slight, and deficient in particularity. We may read sometimes of an epidemic and heavy rains impeding operations, as in 518 A.c. against the Gallic tribes beyond the Po. In the campaign of Cæsar against Pompey, mention is made of autumnal fever, which affected largely the troops of the former. It appears to have been the common fever of the south of Italy, in that time of year when, according to the poet, a quartan fever is looked forward to as a "blessing."

In the pages of Pliny scurvy would again appear to be indicated, under the same names as in the account from Strabo. Might we condescend to more modern times, we should find far more particularity in the Comte de Joinville's memoirs of his campaign in Egypt, during the crusades in the 13th century, with Louis IX. of France:

"You must know," he says, "we eat no flesh the whole of Lent, but eelpouts, which is a gluttonous fish, and feeds on dead bodies. ${ }^{2}$ From this cause and from the bad air of the country, for it rarely rains a drop, the whole army was the subject of a shocking disorder, which dried the flesh of our legs to the bones, and our skins became as black as the ground, or like an old boot that had lain long in a coffer. In addition to this miserable disorder, those affected by it had another sore complaint in the mouth from eating such fish, that rotted the gums and caused a stinking breath. Very few escaped death that were thus attacked, and the surest symptom of its being fatal was a bleeding at the nose; when that took place, none recovered."

This gives us a description of dry gangrene such as might reach our breakfast table any morning in news from the American army through the New York papers, as well as of scurvy in its most virulent form.

In closing this article we may say, if the present happily existing interest attaching to sanitary questions ever rise to the height and breadth of popular diffusion, so that each man should come to know the interest he has in studying and arriving at truth in these questions - the soldier no less than the officer carrying with him the traditions of health, and chiding the neglect of precautions against disease-it will be owing, we think, in the first place, to the liberal and fearless expression of the medical profession, both within and beyond the walls of the service. We have always ourselves been willing, without prejudice to the truth or public necessity, to give an opportunity for such expression - a most necessary benefit to the military profession, in which esprit du corps and uniformity of habit is too apt to enclose and narrow that breadth of view which is required to contend with the varying obstinacies of nature, and well calculated, as regards their medical department, to stimulate sagacity and to nourish zeal.

2 In fact, these fish were taken in the Thanis, a neighbouring canal, in which
$\quad$ Jurtanam. Sat. iv. 57. Christian and paynim bodies, in prodigious numbers, found a ready sepulchre. 